\title{
Contribution of glutamate decarboxylase in Lactobacillus reuteri to acid resistance and persistence in sourdough fermentation
}

\author{
Marcia S Su, Sabine Schlicht, Michael G Gänzle* \\ From 10th Symposium on Lactic Acid Bacterium \\ Egmond aan Zee, the Netherlands. 28 August - 1 September 2011
}

\begin{abstract}
Background: Acid stress impacts the persistence of lactobacilli in industrial sourdough fermentations, and in intestinal ecosystems. However, the contribution of glutamate to acid resistance in lactobacilli has not been demonstrated experimentally, and evidence for the contribution of acid resistance to the competitiveness of lactobacilli in sourdough is lacking. It was therefore the aim of this study to investigate the ecological role of glutamate decarboxylase in L. reuteri.
\end{abstract}

Results: A gene coding for a putative glutamate decarboxylase, gadB, was identified in the genome of L. reuteri 100-23. Different from the organization of genetic loci coding for glutamate decarboxylase in other lactic acid bacteria, gadB was located adjacent to a putative glutaminase gene, g/s3. An isogenic deletion mutant, L. reuteri $\triangle g a d B$, was generated by a double crossover method. L. reuteri 100-23 but not L. reuteri $\triangle g a d B$ converted glutamate to $\gamma$-aminobutyrate (GABA) in phosphate butter ( $\mathrm{pH}$ 2.5). In sourdough, both strains converted glutamine to glutamate but only L. reuteri 100-23 accumulated GABA. Glutamate addition to phosphate buffer, $\mathrm{pH} 2.5$, improved survival of L. reuteri 100-23 100 -fold. However, survival of $L$. reuteri $\triangle g a d B$ remained essentially unchanged. The disruption of gadB did not affect growth of $L$. reuteri in mMRS or in sourdough. However, the wild type strain L. reuteri 100-23 displaced L. reuteri $\triangle$ gadB after 5 cycles of fermentation in back-slopped sourdough fermentations.

Conclusions: The conversion of glutamate to GABA by L. reuteri 100-23 contributes to acid resistance and to competitiveness in industrial sourdough fermentations. The organization of the gene cluster for glutamate conversion, and the availability of amino acids in cereals imply that glutamine rather than glutamate functions as the substrate for GABA formation. The exceptional coupling of glutamine deamidation to glutamate decarboxylation in L.Â reuteri likely reflects adaptation to cereal substrates.

\section{Background}

Sourdough is used in bread production as a leavening agent, or as a baking improver to improve the texture, flavour, and shelf life of bread [1,2]. Sourdoughs used as the sole leavening agent (type I sourdoughs) are maintained by frequent back-slopping. These conditions select for fast growing microorganisms, and type I sourdough microbiota are typically dominated by Lactobacillus

\footnotetext{
* Correspondence: mgaenzle@ualberta.ca

University of Alberta, Department of Agricultural, Food and Nutritional Science, Edmonton, Canada

Full list of author information is available at the end of the article
}

sanfranciscensis[3-5]. Industrial sourdoughs used for the production of baking improvers (type II sourdoughs) are fermented at $35-40^{\circ} \mathrm{C}$ for extended fermentation times ( $2-5$ days) to achieve high levels of total titrable acidity $[1,3]$. These sourdoughs are typically dominated by thermophilic, acid-tolerant lactobacilli, including Lactobacillus pontis, and Lactobacillus panis[3-5]. Lactobacillus reuteri is generally considered an intestinal organism [6] but also occurs in type II sourdoughs [3-5], and was shown to persist in an industrial sourdough fermentation over a period of more than one decade, corresponding to several 10,000 generations of bacterial growth [7]. Model 
sourdough fermentations confirmed that long fermentation times at high temperature $\left(42^{\circ} \mathrm{C}\right)$ select for $L$. reuteri $[8,9]$.

Owing to long fermentation times, acid stress impacts the persistence of lactobacilli in type II sourdough fermentation. Mechanisms of acid tolerance in Gram-positive bacteria generally include the expression of stress proteins, the overexpression of proton pumps, and modification of metabolic pathways to consume protons $[10,11]$. Remarkably, metabolic pathways contributing to acid resistance of L. reuteri also improve bread quality. The formation of dextran, reuteran, or levan by lactic acid bacteria contributes to acid resistance [12,13] and improves bread texture and volume [14]. Conversion of arginine to ornithine improves the acid resistance of $L$. reuteri $[10,15,16]$. Ornithine is also a precursor of the character impact compound of wheat bread crust flavour, 2-acetyl-1-pyrroline [17]. The deamidation of glutamine to glutamate by sourdough lactobacilli generates umami taste in sourdough bread, and improves growth of $L$. reuteri at low pH [18].

Glutamate decarboxylation to $\gamma$-aminobutyric acid (GABA) contributes to the acid resistance of Escherichia coli, Listeria monocytogenes, and Lactococcus lactis[19-21]. The antiport of glutamate and GABA generates a $\Delta \mathrm{pH}$ and $\Delta \Psi$ contributing to a proton motive force for ATP synthesis [22]. However, although glutamate decarboxylases were biochemically characterized in L. brevis and L. paracasei $[23,24]$, the physiological function of glutamate decarboxylase in aciduric Lactobacillus is unclear. Moreover, experimental evidence for the contribution of any acid resistance mechanism to the competitiveness of lactobacilli in sourdough is lacking. It was therefore the aim of this study to investigate the ecological role of glutamate decarboxylase in cereal-associated L. reuteri. Experiments were conducted with $L$. reuteri 100-23 [25]. This strain has a known genome sequence, harbours a glutamate decarboxylase, and decarboxylates glutamate during sourdough fermentation [26]. An isogenic deletion mutant, $L$. reuteri $\triangle \operatorname{gadB}$, was generated by a double crossover method to elucidate the importance of GadB in acid resistance and the competitiveness in type II sourdoughs.

\section{Methods}

\section{Strains, plasmids and media}

Bacterial strains and plasmids used in this study are shown in Table 1. Escherichia coli JM109 (Promega, Nepean, Canada) was cultured in Luria-Bertani (LB) broth at $37^{\circ} \mathrm{C}$ or $30^{\circ} \mathrm{C}$. L. reuteri was cultured at $37^{\circ} \mathrm{C}$ in deMan-RogosaSharpe broth (MRS) (Difco, Mississauga, Canada) or modified MRS medium [7]. Ampicillin (100 $\left.\mathrm{mg} \mathrm{L}^{-1}\right)$ or erythromycin (500 $\mathrm{mg} \mathrm{L}^{-1}$ ) was added to LB for selecting antibiotic-resistant E. coli. Erythromycin $\left(10 \mathrm{mg} \mathrm{L}^{-1}\right)$ was added to MRS medium to select erythromycin-resistant L. reuteri.

\section{DNA manipulation}

DNA was isolated from overnight cultures using the Blood \& Tissue Kit (Qiagen, Mississauga, Canada) according to instructions of the manufacturer. Oligonucleotides were purchased from Integrated DNA Technologies (San Diego, CA), restriction enzymes from New England Biolabs (Pickering, Canada), T4 DNA ligase from Epicentre (Markham, Canada) and Taq DNA polymerase from Invitrogen (Burlington, Canada). DNA sequencing was performed by Macrogen (Rockville, Maryland).

\section{Amino acid comparison of gadB genes and the gene loci in lactic acid bacteria}

The glutamate decarboxylase (GadB) protein sequence of Lactobacillus paracasei[24] (GI:169264609) was used to identify a homologous gene encoding $\operatorname{gadB}$ in the genome of L. reuteri 100-23 (http://www.jgi.doe.gov/) [27]. Gene loci of putative gadB genes and flanking nucleotide sequences in Lactococcus lactis subsp. cremoris MG1363 [21], L. reuteri 100-23 and L. plantarum WCFS1 [28] were analyzed with the BLASTx program against the National Center for Biotechnology Information databases (http://blast.ncbi.nlm.nih.gov/Blast.cgi). The protein sequences of GadB from various species were retrieved from Uniprot database and aligned to calculate the score of similarity using Geneious alignment (Geneious version 5.1.6, http://www.geneious.com).

Generation and verification of the $L$. reuteri $\Delta$ gadB mutant The gene coding for GadB in L. reuteri 100-23 was truncated using pJRS233 [29] according to a deletion strategy described earlier [30]. A 5' 1016-bp fragment of gadB was amplified from genomic DNA of L. reuteri 100-23 using primers gadB-KO1-Pst (5'-AACTGCAGGTTCAATTTTCAGCACATG-3') and $\operatorname{gadB-KO2-XbaI}\left(5^{\prime}-\right.$ GCTCTAGATATCCTGCCATAGATAAAACCTC-3'). The amplicon was ligated into pGEMTeasy vector (Promega) to generate pGadB-A. The plasmid pGadB-B containing the 3' flanking fragment of $\operatorname{gadB}$ was created using $g a d B-K O 3-X b a I$ (5' - GCTCTAGATTCACTCATTAAACCTTAGAA-3') and $\operatorname{gadB-KO} 4-B a m H I$ (5'CGGGATCCAATGGCTGCAGGGATA-3'). The flanking fragments of $\operatorname{gadB}$ from these plasmids were digested with the respective restriction enzymes, purified, and ligated to create $\mathrm{pGadB}-\mathrm{AB}$. The DNA fragment in pGadB-AB was cut with Pst I and BamHI and ligated into the PstI-BamHI sites in pJRS233. The resulting plasmid pKO-gadB-AB was electrotransformed in competent $L$. reuteri $100-23$ cells resuspended in water with $30 \%$ (v/v) polyethylene glycol (MW 3350; J.T. Baker Chemical, Phillipsburg, NJ). Transformants were grown in mMRSerythromycin broth at $42-44^{\circ} \mathrm{C}$ for 80 generations to select for single crossover mutants. L. reuteri with $\mathrm{pKO}$ gadB-AB integrated into chromosome were cured by 
Table 1 Bacterial strains and plasmids used in this study

\begin{tabular}{|c|c|c|}
\hline Strain or plasmid & Genotype & Source or reference \\
\hline \multicolumn{3}{|c|}{ Strains } \\
\hline Escherichia coli JM109 & Cloning host for pGEMTeasy- and pJRS233-derivative plasmids & Promega \\
\hline Lactobacillus reuteri $100-23$ & Rodent isolate; wild type strain & [25] \\
\hline$\Delta g a d B$ & Wild-type strain derivative with a deletion in gadB & This study \\
\hline \multicolumn{3}{|c|}{ Plasmids } \\
\hline pGEMTeasy & Cloning vector used in E. coli; $3.0 \mathrm{~kb}$; Amp ${ }^{r}$ & Promega \\
\hline pGadB-A & pGEMTeasy containing $1 \mathrm{~kb}$ of the DNA sequence upstream of gadB; $4.0 \mathrm{~kb}$; Amp ${ }^{r}$ & This study \\
\hline pGadB-B & pGEMTeasy containing $0.9 \mathrm{~kb}$ of the DNA sequence downstream of gadB; $3.9 \mathrm{~kb}$; $\mathrm{Amp}^{\mathrm{r}}$ & This study \\
\hline pGadB-AB & pGEMTeasy containing the upstream and downstream sequences of gadB; $4.9 \mathrm{~kb}$; Amp ${ }^{r}$ & This study \\
\hline pJRS233 & Shuttle vector used in the hosts E. coli and L. reuteri 100-23; $6.0 \mathrm{~kb}^{-} \mathrm{Erm}^{\mathrm{r}}$ & [29] \\
\hline $\mathrm{pKO}-\mathrm{gadB}-\mathrm{AB}$ & pJRS233 containing $1.9 \mathrm{~kb}$ of the flanking sequences of gadB; $7.9 \mathrm{~kb}$; Erm ${ }^{\mathrm{r}}$ & This study \\
\hline
\end{tabular}

$\mathrm{Amp}^{\mathrm{r}}$ : amplicillin-resistance gene; Erm ${ }^{\mathrm{r}}$ : erythromycin-resistance gene.

culturing in mMRS broth at $37^{\circ} \mathrm{C}$ for 100 generations. The culture was plated on mMRS agar and erythromycin-sensitive double crossover mutants were identified by replica plating mMRS and mMRS-erythromycin agar. The truncation of $\operatorname{gadB}$ in L. reuteri 100-23 $\triangle$ gadB was confirmed by PCR with the primers gadB-KO1-PstI and gadB-KO4-BamHI. An amplicon with the expected size of $3000 \mathrm{bp}$ was obtained with DNA from the L. reuteri 100-23 as template. PCR with DNA from $L$. reuteri 100$23 \triangle \operatorname{gadB}$ yielded a $2000 \mathrm{bp}$ amplicon. A second PCR with primers $g a d B-5 \mathrm{~F}$ (5'-GGTCTTATTACCGTTCCTAAT-3') and $\operatorname{gadB}-6 \mathrm{R}$ (5'-ACATTTCTTATGGGATTGCAT-3') yielded $1700 \mathrm{bp}$ and $500 \mathrm{bp}$ amplicons from the L. reuteri 100-23 and L. reuteri $\triangle \operatorname{gadB}$, respectively. DNA sequencing was conducted to verify the deletion region using primers $\operatorname{gadB}-5 \mathrm{~F}$ and $\operatorname{gadB}-6 \mathrm{R}$.

\section{Growth in mMRS and survival at $\mathbf{p H} 2.5$}

Growth of $L$. reuteri $100-23$ and $L$. reuteri $\triangle \operatorname{gadB}$ was assessed in mMRS (pH 6.7) and mMRS acidified to $\mathrm{pH}$ values of 4.7 and 3.8. Media were inoculated with overnight cultures, incubated at $37^{\circ} \mathrm{C}$, and growth was monitored by measuring the optical density (OD) at $600 \mathrm{~nm}$. To evaluate acid resistance, overnight grown cultures were harvested by centrifugation, washed in $50 \mathrm{mM} \mathrm{Na}_{2} \mathrm{HPO}_{4}$ buffer ( $\mathrm{pH} 7$ ), and resuspended in $50 \mathrm{mM}$ potassium phosphate buffer ( $\mathrm{pH} 2.5)$ to an $\mathrm{OD}_{600 \mathrm{~nm}}$ of 1.0. To assess the contribution of amino acid metabolism to acid resistance, parallel experiments were conducted in potassium phosphate buffer ( $\mathrm{pH} 2.5)$ supplemented with $10 \mathrm{mM}$ glutamate or arginine. A pH of 2.5 adjusted with $\mathrm{HCl}$ was chosen to match conditions previously used to determine the effect of glutamate decarboxylase on acid resistance in E. coli and L. monocytogenes $[10,19,20]$. Samples were taken after $0,1,3,5,8$ and $24 \mathrm{~h}$ of incubation at $\mathrm{pH} 2.5$ for quantification of amino acids (see below), and to monitor bacterial survival. For determination of bacterial survival, samples were immediately mixed with phosphate buffered saline (PBS, $137 \mathrm{mmol} \mathrm{L}^{-1} \mathrm{NaCl}, 2.7 \mathrm{mmol} \mathrm{L}{ }^{-1}$ $\mathrm{KCl}, 10 \mathrm{mmol} \mathrm{L}^{-1} \mathrm{Na}_{2} \mathrm{HPO}_{4}$, and $2 \mathrm{mmol} \mathrm{L}^{-1} \mathrm{KH}_{2} \mathrm{PO}_{4}$, $\mathrm{pH}$ 8.0) and diluted in PBS buffer prior to plating on MRS agar. For the samples of $24 \mathrm{~h}$ acid treatment, $10 \mathrm{~mL}$ of culture was centrifuged, resuspended in PBS buffer and plated on MRS agar to determine the bacterial survival. Growth curves and survival at pH 2.5 were determined in triplicate independent experiments.

\section{Sourdough fermentations and sampling}

Sourdough fermentations were performed with $L$. reuteri 100-23 and L. reuteri $\triangle$ gadB to examine the effect of glutamate decarboxylase on growth, acidification, $\mathrm{pH}$, and amino acid concentrations. Doughs were prepared from $40 \mathrm{~g}$ whole wheat flour and sterile tap water to achieve a dough yield of 200 [(dough mass/flour mass $) \times 100$ ], and inoculated at $37^{\circ} \mathrm{C}$ with an initial cell count of $1 \pm 0.5 \times$ $10^{7} \mathrm{CFU} \mathrm{g}{ }^{-1}$. Initially, sourdoughs were inoculated with L. reuteri $100-23$ or $L$. reuteri $\triangle$ gadB separately, and samples were collected after $0,6,12,24,48,72$, and $96 \mathrm{~h}$ of fermentation. In a second experiment, $L$. reuteri 100-23 and $\triangle \operatorname{gadB}$ were co-cultured in the same sourdough. Doughs were fermented for $96 \mathrm{~h}$ (trial I), or for $240 \mathrm{~h}$ by backslopping every $48 \mathrm{~h}$ (trial II) to match conditions known to select for L. reuteri[8]. At each refreshment step, $5 \%$ of the ripe sourdough was used as an inoculum for the subsequent fermentation. Samples were taken to measure $\mathrm{pH}$ and viable cell counts. The dough samples were stored at $-20^{\circ} \mathrm{C}$ for subsequent DNA extraction and amino acid analysis (see below). Sourdough fermentations were carried out in two independent experiments, and each sample was analyzed in duplicate.

\section{Quantification of amino acids by HPLC}

Cells from phosphate buffer ( $\mathrm{pH}$ 2.5) were removed by centrifugation. The supernatant $(1 \mathrm{vol})$ was mixed with deionized water $(4 \mathrm{vol})$, saturated potassium borate $(4 \mathrm{vol})$ and $\beta$-aminobutyric acid used as internal standard ( $1 \mathrm{vol})$. 
Sourdough samples were lyophilized, extracted with water at an extraction ratio of 1:6 (w/v) and diluted with water, potassium borate, and internal standard as described above. Amino acids were quantified by HPLC after derivatisation with $o$-phtaldialdehyde [31].

\section{Extraction of DNA from sourdough}

Two grams of sourdough were washed with $4 \mathrm{ml}$ of PBS buffer (pH 7.8) and resuspended in PBS. Flour solids were removed by $1500 \times g$ for $10 \mathrm{~min}$ and cells were harvested by centrifugation at $13,000 \times g$. Cells were resuspended in $660 \mu \mathrm{L}$ lysis buffer $\left(10 \mathrm{mmol} \mathrm{L}^{-1}\right.$ Tris- $\mathrm{Cl}, 0.5 \mathrm{mmol} \mathrm{L}^{-1}$ EDTA, 10\% SDS, pH 7.5), and incubated at $65^{\circ} \mathrm{C}$ for $10 \mathrm{~min}$. Protein was precipitated by addition of $340 \mu \mathrm{L}$ $5 \mathrm{~mol} \mathrm{~L}^{-1}$ potassium acetate and incubation at $-20^{\circ} \mathrm{C}$ for $10 \mathrm{~min}$. After centrifugation, $900 \mu \mathrm{L}$ of the supernatant was mixed with an equal volume of isopropanol, DNA was pelleted by centrifugation and washed with $95 \%$ ice-cold ethanol. DNA was resuspended in $20 \mu \mathrm{L}$ of $10 \mathrm{mmol} \mathrm{L}^{-1}$ Tris-Cl (pH 8.5), and the DNA concentration was determined by UV spectrometry using a NanoDrop spectrophotometer ND-1000 (Thermo Fisher Scientific Inc., Wilmington, DE, USA).

\section{Quantification of bacterial population in sourdough using} quantitative PCR (qPCR)

The cell counts of $L$. reuteri $100-23$ relative to the L. reuteri $\triangle g a d B$ was quantified using a probe-based qPCR assay targeting the native and disrupted regions of $\operatorname{gadB}$, respectively. Two $\mu \mathrm{g}$ of chromosomal DNA of L. reuteri $100-23$ and $L$. reuteri $\triangle g a d B$ were digested separately with NotI, purified and diluted to a known DNA concentration corresponding to a known copy number $\operatorname{gadB}$ or $\triangle \operatorname{gadB}$ for use as standards. DNAs extracted from sourdough were also digested with NotI and purified using the QIAquick PCR Purification kit (Qiagen). Strain-specific primers and probes were designed using Primer Express Software 3.0 (Applied Biosystems, Streetsville, Ontario, Canada). Primers and probe specific for L. reuteri 100-23 (WT-qPCR-F, 5'TGGGATTTCCAACTAAAGAATGTTG-3'; WT-qP CR-R, 5'-CAACCAATACCAGGATAAACTAAACCA3'; and WT-qPCR-probe, 5'-Hex/TCCATTAACGCT TCCGGCCACAAGT/IABkFQ-3') target the DNA region of gene $\operatorname{gadB}$, which is deleted in $L$. reuteri $\triangle \operatorname{gadB}$ strain. Primers and probe specific for $L$. reuteri $\triangle \operatorname{gadB}(\triangle \operatorname{gadB}$-qPCR-F, 5'-CATATCATTGCAAATTC AGACGAAA-3'; $\triangle$ gadB-qPCR-R, 5'-ATCTAAGCAA GTTGTTATGCTTGTTTAGATC-3'; and $\triangle \operatorname{gadB}$ qPCR-probe (5'-TET/CCTAGGAGGTTTTATCTATG GCAGGATAATCTAGATTCAC/IABkFQ-3') target the joint site of deleted $\operatorname{gadB}$ sequence which is absent in the wild type strain. PCR was carried out with Rox Brilliant II Master Mix (Stratagene, Mississauga,
Ontario, Canada) in a 7500 Fast Real-time PCR instrument (Applied Biosystems). Standard curve, determination of the PCR efficiency, and calculation of the copy number were carried out with 7500 Fast System SDS v1.4 software.

\section{Nucleotide accession numbers}

DNA sequences of L. reuteri 100-23 were obtained from the National Center for Biotechnology Information databases (GenBank: AAPZ02000002.1). The gene regions of predicted glutamate $/ \gamma$-aminobutyrate antiporter ( $\operatorname{gad} C 2)$, glutaminase $(g l s 3)$, glutamate $/ \gamma$-aminobutyrate antiporter ( $\operatorname{gadC1})$, glutamate decarboxylase $(\mathrm{gadB})$ and xanthine/uracil/vitamin C permease are 549316.550869, complement (548219..549139), complement (546271..547809), complement (544847..546253) and 543444..544787, respectively. The sequence of the truncated $\mathrm{gadB}$ in L. reuteri $\Delta \operatorname{gadB}$ was deposited with accession number JF339969.

\section{Results}

Gene locus coding for glutamate metabolism in L. reuteri Genome analysis of L. reuteri 100-23 revealed a gene cluster encoding proteins homologous to glutamate decarboxylase $(\operatorname{gadB})$, glutamate: $\gamma$-aminobutyric acid (GABA) antiporters ( $g a d C 1$ and $g a d C 2$ ), a glutaminase ( $g l s 3$ ), and a xanthine/uracil/vitamin C permease (Fig. 1). The GadB sequence is $69 \%, 64.4 \%, 63.7 \%$, and $51.1 \%$ similar to that of L. lactis MG1363 [21], L. plantarum WCFS1 [28], L. brevis OPK-3 [32], and L. paracasei[24], respectively, suggesting that $\operatorname{gadB}$ of $L$. reuteri 100-23 encodes a glutamate decarboxylase. However, the organisation of the $\operatorname{gadB}$ gene locus in $L$. reuteri differs from related lactic acid bacteria as it also contains one of three glutaminases encoded in the genome of L. reuteri 100-23. In Lactococcus lactis subsp. cremoris MG1363, gadB is accompanied by gadC and $\operatorname{gadR}$, which is a positive regulator of $\operatorname{gadBC}$, and is adjacent to the glutamate synthase domains $g l t B$ and $g l t C$. In L. plantarum WCFS1, gadB is not located adjacent to other genes related to glutamine or glutamate metabolism.

\section{Creation of a gadB deletion mutation in L. reuteri}

A deletion in $\operatorname{gadB}$ of $L$. reuteri 100-23 was generated by a double crossover mutagenesis method. The deletion in the resulting strain $L$. reuteri 100-23 $\triangle \operatorname{gadB}$ was confirmed by DNA sequencing. The impact of $\operatorname{gadB}$ mutation on bacterial growth was investigated in mMRS and acidified mMRS (Fig. 2). Wild-type L. reuteri and the $\triangle$ gadB mutant grew similarly in mMRS (pH 6.7, 4.7 and 3.8), indicating that the growth of $L$. reuteri $\triangle \operatorname{gadB}$ in complex media was not affected.

\section{Survival of $L$. reuteri $\Delta g a d B$ at $\mathrm{pH} 2.5$}

To confirm that gadB of $L$. reuteri encoded glutamate decarboxylase contributes to acid resistance, amino acid 


\section{Lactococcus lactis subsp. cremoris MG1363}

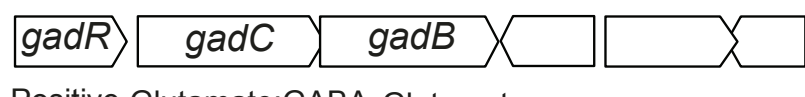

Positive Glutamate:GABA Glutamate regulator antiporter decarboxylase

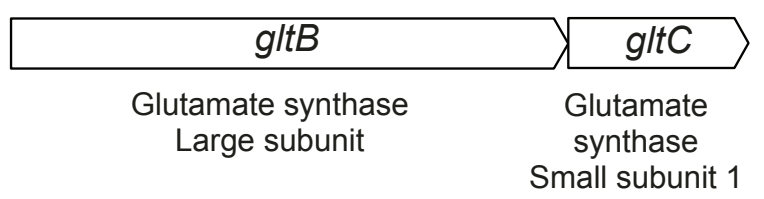

\section{Lactobacillus reuteri 100-23}

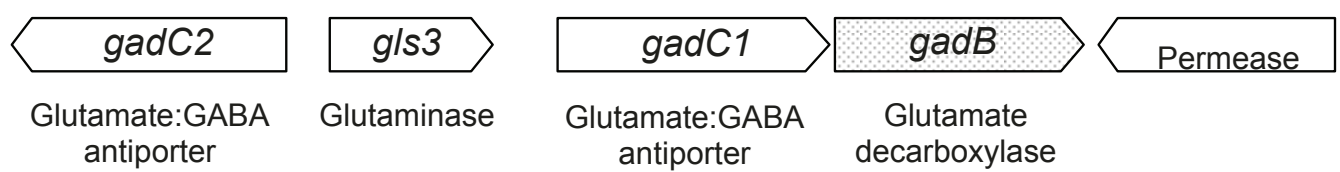

\section{Lactobacillus plantarum WCFS1}
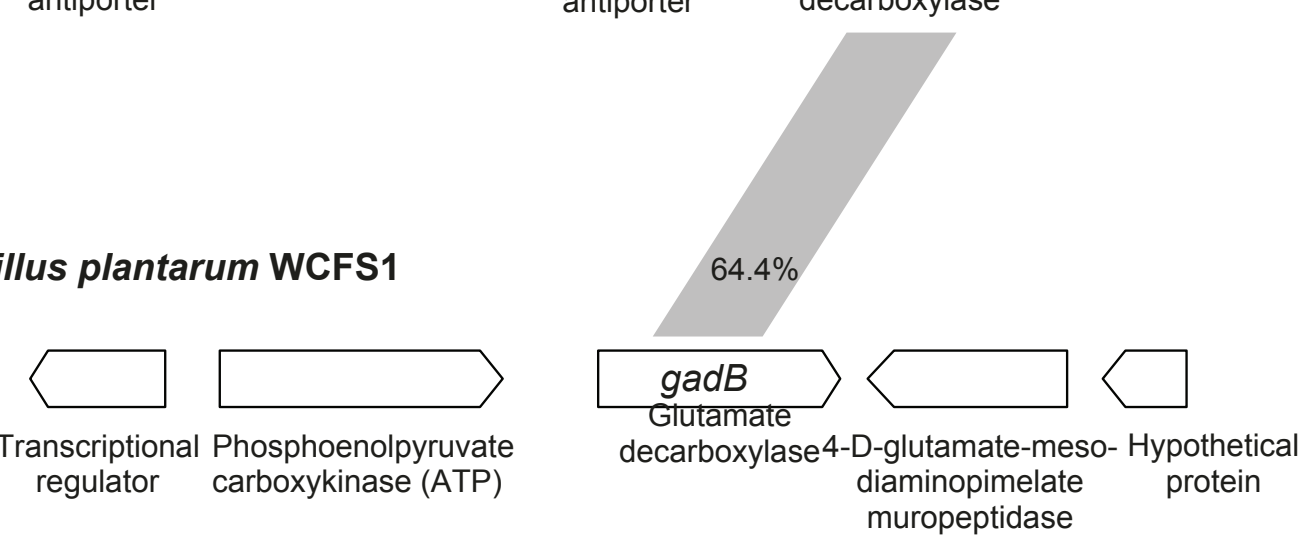

Figure 1 Representation of gene loci encoding glutamate decarboxylases in Lactococcus lactis MG1363, Lactobacillus reuteri 100-23 and Lactobacillus plantarum WCFS1. Numbers indicate protein similarity.

metabolism and survival at $\mathrm{pH} 2.5$ of $L$. reuteri $\triangle \operatorname{gadB}$ were compared to the wild type strain $L$. reuteri 100-23. Disruption of $\operatorname{gadB}$ did not influence the survival of L. reuteri at $\mathrm{pH} 2.5$ in the absence of glutamate (Fig. 3). However, addition of glutamate increased survival of L. reuteri $100-23$ by more than $2 \log$ whereas only a transient effect on survival of $L$. reuteri $\triangle \operatorname{gadB}$ was observed (Fig. 3). Amino acid analysis confirmed that L. reuteri 100-23 but not $L$. reuteri $\triangle$ gadB converted glutamate to GABA. After $24 \mathrm{~h}$ of incubation of L. reuteri 100-23 in phosphate buffer in presence or absence of glutamate, GABA concentration was $2.5 \pm 0.1$ and $0.4 \pm 0.03 \mathrm{mmol}$ $\mathrm{L}^{-1}$, respectively, whereas GABA was not detected in supernatant after incubation of $L$. reuteri $\triangle \operatorname{gadB}$ in presence or absence of glutamate. Taken together, these results demonstrate that $\mathrm{gadB}$ in $L$. reuteri encodes a glutamate decarboxylase which contributes to acid resistance at $\mathrm{pH} 2.5$.
The effect of glutamate on acid resistance of $L$. reuteri 100-23 and L. reuteri $\Delta \operatorname{gadB}$ was compared to the effect of arginine. The effect of arginine on survival of $L$. reuteri 100-23 was comparable to the effect of glutamate (Fig. 3). Notably, L. reuteri $\triangle \operatorname{gadB}$ was more resistant in argininecontaining medium than the wild-type strain, indicating that the loss of the function of acid resistance may be compensated by over-expression of alternative pathways to achieve $\mathrm{pH}$ homeostasis.

\section{Glutamine metabolism of $L$. reuteri $\triangle \operatorname{gadB}$ in sourdough}

Because in vitro acid challenge demonstrated a contribution of GadB to bacterial survival under acidic conditions, stationary phase survival of $L$. reuteri $\triangle g a d B$ in sourdough was compared to the wild type strain (Fig. 4A). Within $12 \mathrm{~h}$ of fermentation, the $\mathrm{pH}$ decreased from 6.6 to 3.8. Growth of the wild-type and $\triangle g a d B$ strains in sourdough was virtually identical, maximum cell counts of $10.7 \pm 0.9$ and $10.5 \pm 0.6$ 


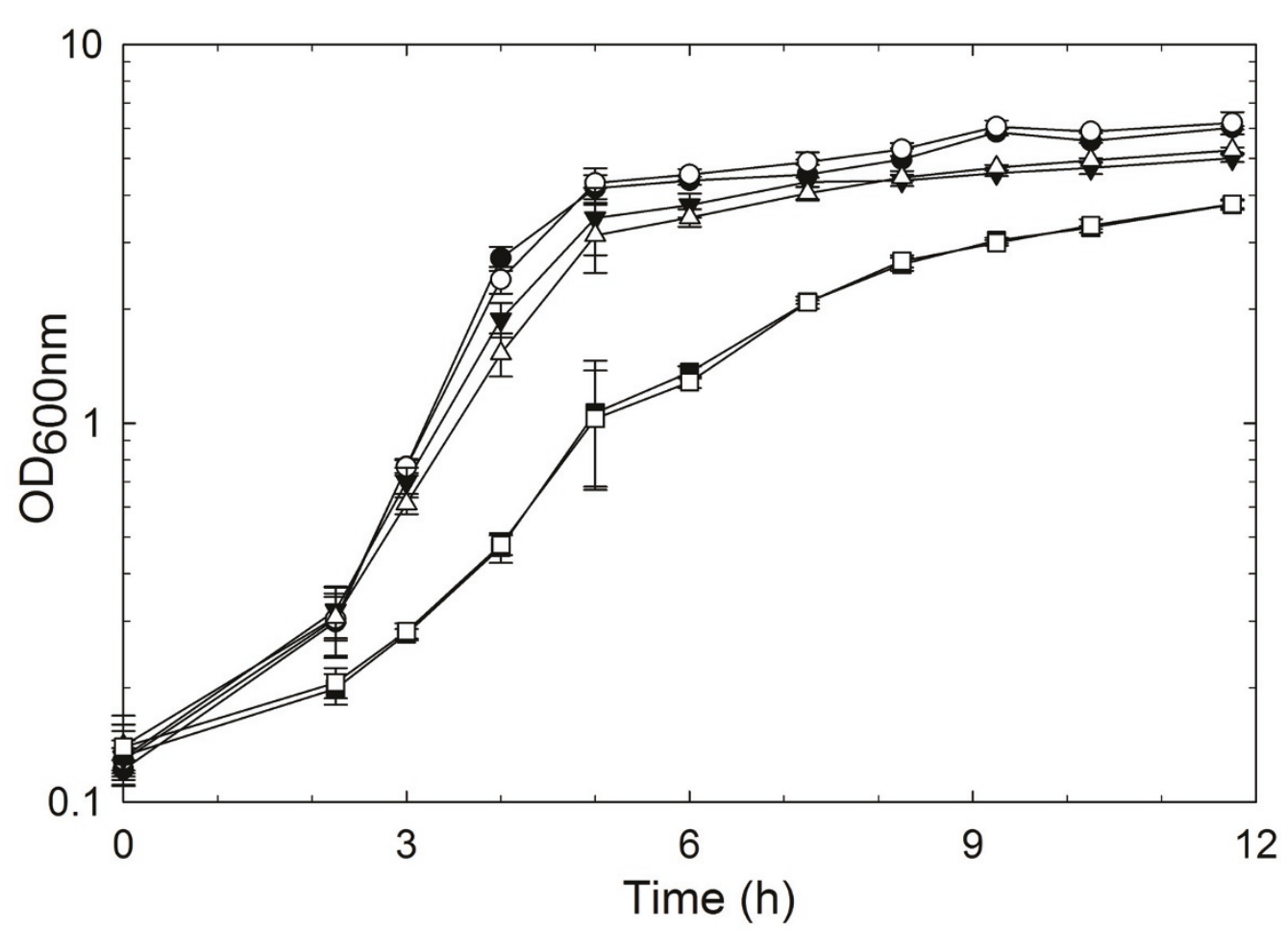

Figure 2 Bacterial growth curve of L. reuteri 100-23 (black symbols) and $\triangle$ gadB (open symbols) strains in mMRS (pH 6.7, •, 0) and HCl-acidified mMRS (pH 4.7,,$\Delta_{;}$pH 3.8, $\mathbf{\bullet}$, 口).

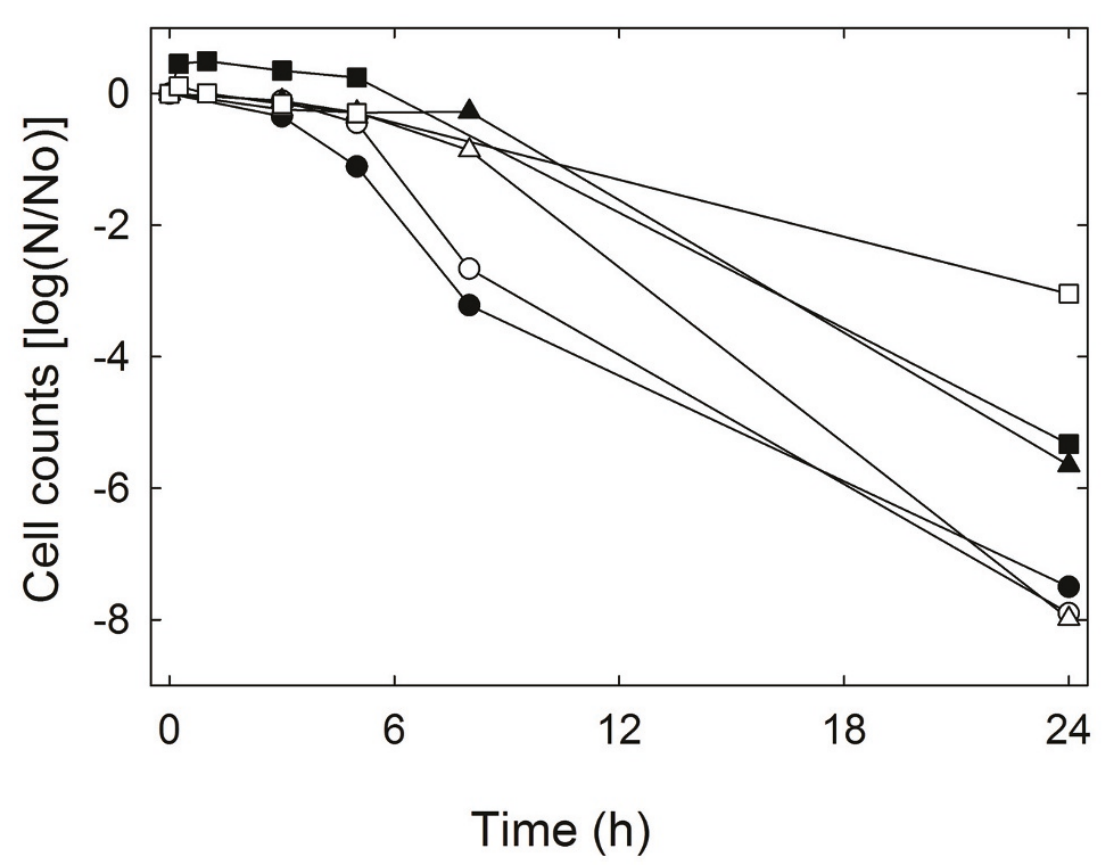

Figure 3 Acid resistance of L. reuteri 100-23 (black symbols) and L. reuteri $\Delta$ gadB (open symbols) in phosphate buffer $(\mathrm{pH} 2.5)(\bullet, 0)$, in phosphate buffer with $10 \mathrm{mM}$ glutamate $(\boldsymbol{\Delta}, \Delta)$, or in phosphate buffer with $10 \mathrm{mM}$ arginine $(\boldsymbol{\bullet}, \square)$. Cell counts are plotted as log $\left(\mathrm{N} / \mathrm{N}_{0}\right)$. Data are representative of three independent experiments and the standard deviations were generally less than 0.3 . 
$\log$ CFU g ${ }^{-1}$, respectively, were reached after $12 \mathrm{~h}$. At $96 \mathrm{~h}$ after fermentation, the $\mathrm{pH}$ was maintained at 3.8 , and the cell counts decreased to $6.5-7.7 \log$ CFU g ${ }^{-1}$. Cell counts of $L$. reuteri $\triangle \mathrm{gadB}$ in sourdough consistently decreased faster than cell counts of the wild type strain. A comparable trend towards improved survival was observed when a GadB positive wild type strain was compared to a GadB negative wild type strain [26], however, in both cases, the difference was smaller than experimental error [Fig. 4A and [26]].

The evaluation of glutamine and glutamate metabolism by L. reuteri $100-23$ and L. reuteri $\triangle \operatorname{gadB}$ in sourdough revealed that disruption of $\operatorname{gad} B$ had no influence on the concentration of total amino acids or the concentration of (glutamine + glutamate + GABA). After $96 \mathrm{~h}$ of incubation, the concentration of total amino acids for the wild type and $\triangle \operatorname{gadB}$ strains were $141 \pm 7$ and $129 \pm$ $8 \mathrm{mmol} \mathrm{kg}^{-1} \mathrm{DM}$, respectively. The concentrations of (glutamine + glutamate + GABA) for the wild type and $\Delta \operatorname{gadB}$ strains were $26 \pm 4$ and $21 \pm 4 \mathrm{mmol} \mathrm{kg}^{-1} \mathrm{DM}$, respectively. In sourdoughs fermented with both strains, glutamine levels remained low through out fermentation, indicating a quantitative conversion by L. reuteri (Fig. 4B). L. reuteri 100-23 converted glutamine to GABA, which accumulated to $25 \mathrm{mmol} \mathrm{kg} \mathrm{kM}^{-1} \mathrm{DM}$ after $96 \mathrm{~h}$ of fermentation (Fig. 4B). In contrast, L. reuteri $\triangle \operatorname{gadB}$ accumulated glutamate. Low levels of GABA at the beginning of the fermentation and in the sourdoughs fermented with $L$. reuteri $\triangle g a d B$ are attributable to interference by tyrosine, whose retention time was close to that of GABA.

\section{Role of gadB in long-term sourdough fermentation}

The disruption of gadB did not significantly influence survival of $L$. reuteri over $96 \mathrm{~h}$ of fermentation. However, in sourdoughs maintained by continuous backslopping, relatively small differences between cell counts in a single batch will accumulate over subsequent fermentation cycles. Therefore, it was investigated whether $\operatorname{gadB}$ disruption affects the ecological fitness of $L$. reuteri $\triangle \operatorname{gadB}$ in competition with the wild type strain in a sourdough that was backslopped every $48 \mathrm{~h}$. A sourdough fermented over $96 \mathrm{~h}$ without backslopping was used for comparison. In sourdough without backslopping, the growth of the co-culture was similar to that of single strains (Fig. 4A and Fig. 5). The relative cell counts of L. reuteri 100-23 and $L$. reuteri $\triangle g a d B$ were determined by qPCR using strain-specific primers and probes. Cell counts of $L$. reuteri 100-23 relative to L. reuteri $\triangle \operatorname{gadB}$ increased slightly from 1.3 to $2.7 \log$ during $96 \mathrm{~h}$ of incubation, suggesting that disruption of $\operatorname{gadB}$ slightly compromised stationary phase survival. In the backslopped sourdoughs, the relative cell counts of $L$. reuteri 100-23 to L. reuteri $\triangle$ gadB also increased from about 1.5 to $2 \log$ during the first fermentation cycle. With every subsequent fermentation cycle, the log ratio (wild type/ $\triangle \operatorname{gadB}$ ) increased by about 0.5 (Fig. 5). At the end of the fifth fermentation cycle, cell counts of $L$. reuteri $100-23$ relative to L. reuteri $\triangle$ gadB were $460: 1$, demonstrating that $\operatorname{gadB}$ in $L$. reuteri is essential for its competitiveness in type II sourdoughs maintained by continuous propagation.

\section{Discussion}

This study investigated the role of $\operatorname{gadB}$ coding for glutamate decarboxylase in the acid resistance of $L$. reuteri, and demonstrated that glutamate decarboxylation contributes to the competitiveness of $L$. reuteri in type II sourdoughs that are propagated by continuous backslopping.

The contribution of metabolic traits of $L$. reuteri to its competitiveness in the intestine was previously evaluated with insertional mutations generated by single-crossover mutagenesis $[6,33]$. This study employed a double crossover method to generate an in-frame deletion of $\operatorname{gadB}$ in L. reuteri 100-23. This approach avoids interference by antibiotic-resistance genes or other plasmid-borne foreign genes that remain on the chromosome of mutant strains generated by single-crossover mutagenesis.

The identification of lactic acid bacteria in sourdoughs was previously determined by using species-specific, semiquantitative denaturing gradient gel electrophoresis (DGGE) $[8,9,34,35]$ or culture-dependent enumeration, followed by strain identification through random amplified polymorphic DNA $[34,36]$. However, culture-dependent enumeration or DGGE fails to account for species or strains that contribute less than $1 \%$ to the total cell counts. The qPCR method used in this study achieved an accurate and consistent relative quantification of L. reuteri 100-23 and $L$. reuteri $\triangle \operatorname{gadB}$ even in sourdoughs in which L. reuteri $\triangle \operatorname{gadB}$ contributed less than $0.5 \%$ of the total population.

Type II sourdough fermentations are characterized by a short period of growth, followed by an extended period of fermentation at pH $3.2-3.6[3,4]$. In long-term sourdough fermentations, cereal proteases continuously supply amino acids from cereal proteins, and thus support bacterial acid resistance based on amino acid metabolism $[17,18]$. Arginine and glutamate often contribute to acid resistance of Gram-negative and Gram-positive bacteria (Fig. 6) [10,15,37].

The arginine deiminase (ADI) pathway generates ATP, consumes intracellular protons, and causes the alkalization of the fermentation substrate [Fig. 6; [10,11,15]]. In keeping with prior studies, arginine improved the survival of $L$. reuteri at pH 2.5 about 10-100 fold [[16], this study]. Glutamate decarboxylase was characterized in L. brevis and L. paracasei[23,24], and GadB-positive lactobacilli were employed to accumulate GABA as a functional food ingredient in food fermentations [26,38]. 


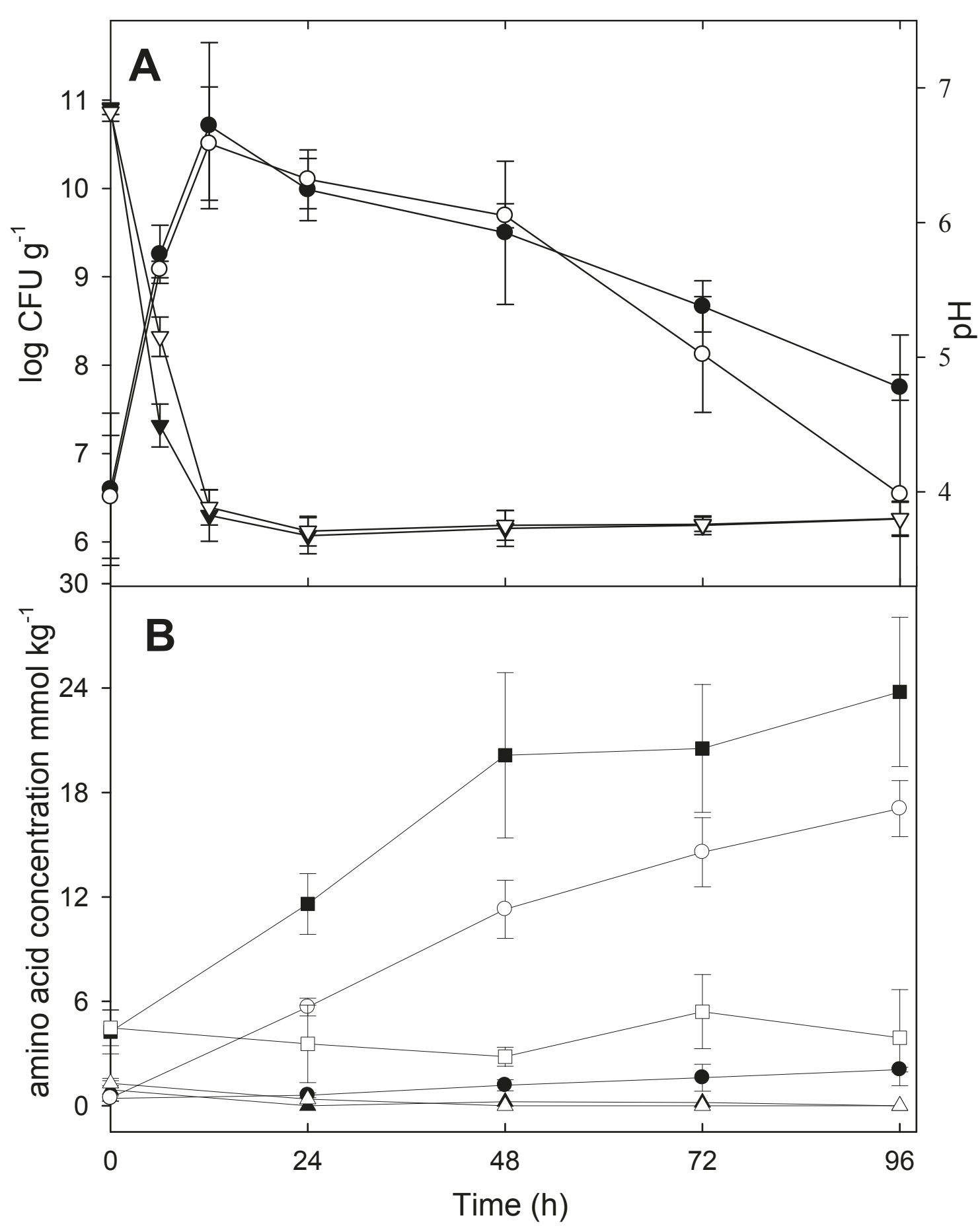

Figure 4 (A) Cell counts $(\bullet, 0)$ and $\mathrm{pH}(\boldsymbol{\nabla}, \nabla)$ of sourdough fermented with L. reuteri 100-23 (black symbols) or L. reuteri $\Delta$ gadB (open symbols) over 96 h. (B) Concentrations of glutamine $(\boldsymbol{\Delta}, \Delta)$, glutamate $(\bullet, 0)$ and $\gamma$-aminobutyric acid $(\boldsymbol{\bullet}$, 口) during sourdough fermentation over $96 \mathrm{~h}$ in $L$. reuteri 100-23 (black symbols) and L. reuteri $\Delta g a d B$ (open symbols). Symbols indicate means \pm standard deviation from quadruplicate determinations. 


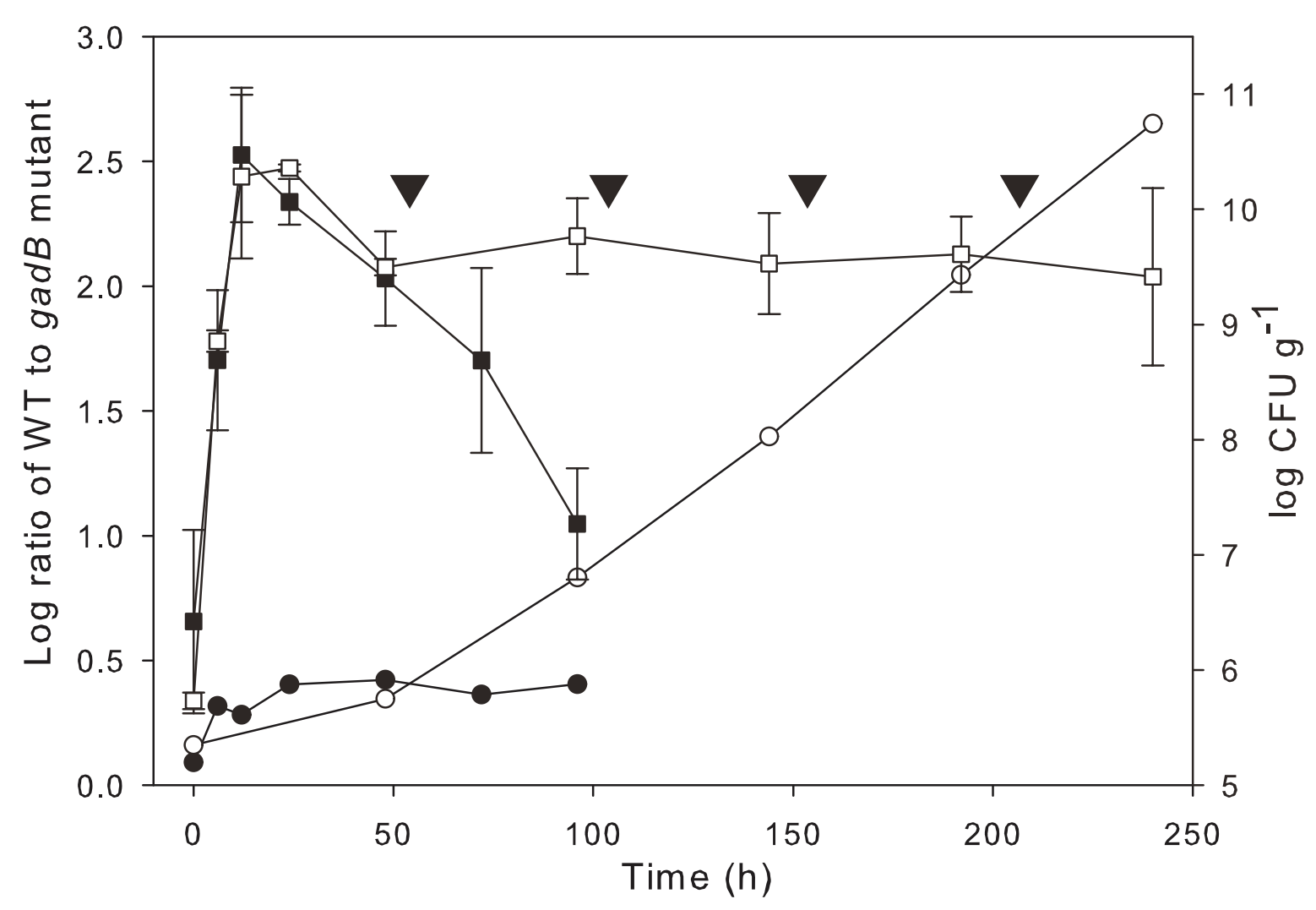

Figure 5 Kinetics of bacterial population in type II sourdough fermentations. Total bacterial cell counts $(-\square)$ were enumerated by plating on mMRS agar. The relative quantification of wild type and mutant strains was achieved by GPCR $(\bullet, 0)$. Sourdoughs were fermented in a single batch over $96 \mathrm{~h}$ (trial l; $\bullet \bullet \bullet$ ), or over $240 \mathrm{~h}$ with refreshment (back-slopping with 5\% inoculum) every $48 \mathrm{~h}$ (trial II; $\square$, ०). The time points of refreshment are indicated $(\nabla)$. Symbols indicate means \pm standard deviation from duplicate independent experiments analysed in duplicate. The standard deviations of cell copy number ratio were less than 0.2 log.

The strain-dependent expression of glutamate decarboxylase in lactobacilli, particularly $L$. reuteri, indicates that GadB is not essential for growth [26]. This was confirmed by comparison of the growth of $L$. reuteri 100-23 and the $\triangle \operatorname{gadB}$ mutant strain in mMRS and sourdough (Figs. 2, 4 and 5). However, although glutamate decarboxylation generally contributes to bacterial resistance to acid $[10,15]$, its contribution to acid resistance in acid-tolerant lactobacilli has not been demonstrated experimentally [26]. Glutamate decarboxylation is particularly effective at $\mathrm{pH}$ values below the $\mathrm{pK}_{\mathrm{A}}$ of GABA, 4.23 , as protonation of GABA below the $\mathrm{pK}_{\mathrm{A}}$ results in alkalization of the external fermentation substrate (Fig. 6). Accordingly, this study demonstrated a protective effect of glutamate decarboxylation at $\mathrm{pH} 2.5$ in buffer, and at pH 3.6 in sourdough. Sourdough is acidified by lactic and acetic acids rather than $\mathrm{HCl}$. However, growth and survival of lactobacilli in sourdough is determined by the $\mathrm{pH}$ and not by the concentration of undissociated organic acids [39]. The protective effect of glutamate on the survival of $L$. reuteri at $\mathrm{pH} 2.5$, an about 100-fold increase of cell counts after acid challenge, is comparable to the effect in $E$. coli $[19,37]$. In $L$. monocytogenes, glutamate addition improved survival after exposure $\mathrm{pH} 2.5$ of a wild type strain more than 6 log compared to a gadAB deficient mutant [20].

A contribution of glutamine deamidation to bacterial acid resistance has not been demonstrated $[10,15,40]$ but glutamine improved the growth of $L$. reuteri and $L$. sanfranciscensis at low $\mathrm{pH}$ [18]. Glutamine accounts for about $30 \%$ of the amino acids wheat proteins but the amount of glutamate is low [41]. Consequently, proteolysis in wheat dough liberates glutamine rather than glutamate $[18,26]$. Glutamate-mediated acid resistance in sourdough thus depends on the conversion of glutamine to glutamate. L. reuteri 100-23 harbours three putative glutaminase genes and $g l s 3$ is located adjacent to $\operatorname{gadB}$. The substrate availability in cereal fermentations and the arrangement of gene loci strongly indicates that the glutamate-based acid resistance of $L$. reuteri 100-23 uses glutamine as a substrate (Fig. 6). In contrast, L. lactis MG1363 has genes coding for glutamine synthase downstream of the $\operatorname{gadBC}$ operon, and in 


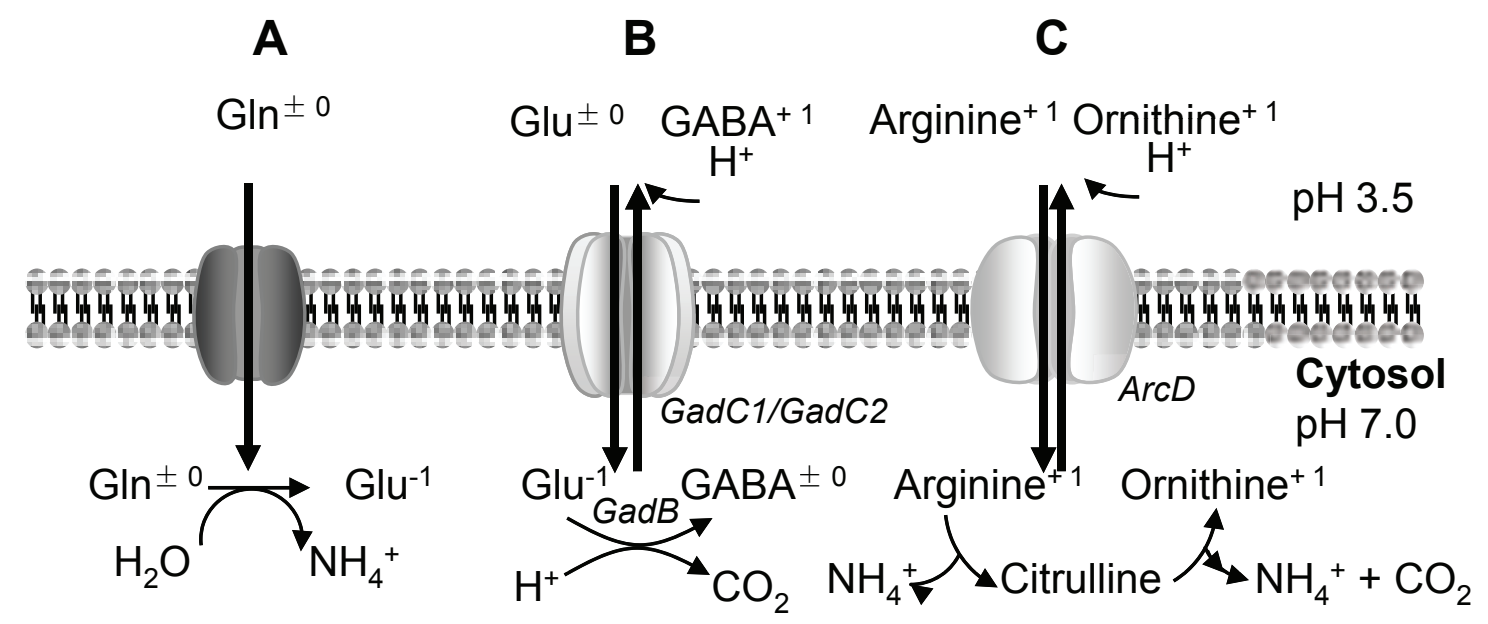

Figure 6 Amino-acid based acid resistance mechanisms in L. reuteri. Following uptake of glutamine by unknown mechanisms, glutaminase

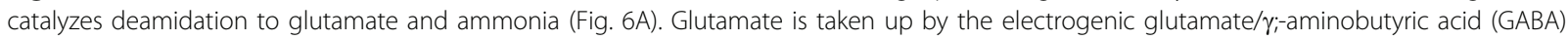
antiport system. Decarboxylation of glutamate consumes an intracellular proton and contributes to generation of $\Delta ; \Psi ;$ and $\Delta ; \mathrm{pH}$. Extracellular protonation of GABA consumes additional protons (Fig. 6B). Arginine is taken up by electroneutral arginine/ornithine exchange. Ammonia generated from arginine contributes to intracellular pH homeostasis; intra- or extracellular protonation of ornithine consumes additional protons (Fig. 6C). GadB: glutamate decarboxylase; GadC: putative glutamate:GABA antiporter; ArCD: putative arginine:ornithine antiporter. Relevant pK values of amino acid side chains and GABA are: glutamate, 4.25; GABA, 4.23; arginine, 12.5; ornithine, 8.69.

L. plantarum WCFS1, no genes related to glutamine metabolism are located close to the $\operatorname{gadB}$ (Fig. 1). The exceptional arrangement of glutamine / glutamate catabolic genes in L. reuteri may reflect the adaptation to cereal substrates. Glutamine:GABA antiport by gadC or analogues has not been shown experimentally [22]. However, ATPdependent glutamate transport enzymes in L. lactis and L. delbrueckii also transport glutamine with high affinity $[42,43]$.

The disruption of $\operatorname{gadB}$ did not influence the survival of $L$. reuteri during long-term sourdough fermentation unless the sourdough was backslopped. The loss of one metabolic pathway for $\mathrm{pH}$ homeostasis in L. reuteri is apparently partially compensated by alternative pathways (Fig. 6). However, monitoring of the microbiota in sourdoughs maintained by continuous backslopping is considered the most appropriate tool to identify competitive strains [8,34-36]. The observation that the wild type strain displaced $L$. reuteri $\triangle \operatorname{gadB}$ after only a few refreshments demonstrates that acid resistance in general and glutamate decarboxylase in particular contributes to the competitiveness of $L$. reuteri in type II sourdoughs.

In addition to its occurrence in sourdough fermentations, $L$. reuteri is recognized as a stable member of the intestinal microbiota of humans and animals, and strains in the species have evolved to colonize the gastrointestinal tracts of specific hosts [6]. In pigs, poultry, and rodents, $L$. reuteri colonizes the pars oesophagus, the crop, and the forestomach, respectively [44]. It is interesting to note that sourdough isolates but not human or poultry isolates of $L$. reuteri are able to colonize rodents $[45,46]$. Colonization and biofilm formation on the stratified, squamous epithelia lining the proximal gastrointestinal tract of animals occurs upstream of the stomach $[44,45]$. Therefore, intestinal $L$. reuteri are exposed to stomach acidity. The conversion of glutamate to GABA in $L$. reuteri is strain-specific but was reported in human, rodent, and sourdough isolates [This study, [26]]. Mechanisms of acid resistance that are relevant in sourdough thus likely contribute to the competitiveness of $L$. reuteri in intestinal ecosystems, and may improve gastro-intestinal survival of $L$. reuteri commercially used as probiotics.

\section{Conclusions}

This study demonstrated that the conversion of glutamate to GABA by L. reuteri $100-23$ contributes to acid resistance and to competitiveness in type II sourdough fermentations. The organization of the gene cluster for glutamate conversion, and the availability of amino acids in cereals imply that glutamine rather than glutamate functions as the substrate for GABA formation. The exceptional coupling of glutamine deamidation to glutamate decarboxylation in L.Â reuteri may reflect ecological adaptation to cereals, or to the proximal intestinal tracts of animals that predominantly feed on cereal grains. 


\section{List of abbreviations used}

MRS: deMan-Rogosa-Sharpe medium; LB: Luria-Bertani broth; GABA: $\gamma$ aminobutyrate; HPLC: high performance liquid chromatography; PBS: phosphate buffered saline; qPCR: quantitative real time polymerase chain reaction.

\section{Acknowledgements}

The authors would like to thank Dr. Shih-Tung Liu for the critical discussions, Dr. Jens Walter for the access to the JGI and IMG databases. NSERC is acknowledged for funding. M. Gänzle acknowledges the Canada Research Chairs Program for financial support.

This article has been published as part of Microbial Cell Factories Volume 10 Supplement 1, 2011: Proceedings of the 10th Symposium on Lactic Acid Bacterium. The full contents of the supplement are available online at http:// www.microbialcellfactories.com/supplements/10/S1.

\section{Authors' contributions}

MGG initiated and coordinated the project; MSS and SS planned and performed the experiments. MSS and MGG wrote the paper. All authors approved the final version of the manuscript.

\section{Competing interests}

The authors declare that they have no competing interests.

Published: 30 August 2011

\section{References}

1. Brandt MJ: Sourdough products for convenient use in baking. Food Microbiol 2007, 24:161-164.

2. Brandt MJ: Geschichte des Sauerteiges. In Handbuch Sauerteig.. 6 edition. Hamburg: Behr's Verlag;Gänzle MG, Brandt MJ 2006:1-5.

3. Böcker G, Stolz P, Hammes WP: Neue Erkenntnisse zum :Ökosystem Sauerteig und zur Physiologie der sauerteigtypischen Stämme Lactobacillus sanfrancisco und Lactobacillus pontis. Getreide Mehl Brot 1995, 49:370-374.

4. Vogel RF, Knorr R, Müller MRA, Steudel U, Gänzle MG, Ehrmann MA: Nondairy lactic fermentations: The cereal world. Antonie van Leeuwenhoek 1999, 76:403-411.

5. De Vuyst L, Vrancken G, Ravyts F, Rimaux T, Weckx S: Biodiversity, ecological determinants, and metabolic exploitations of sourdough microbiota. Food Microbiol 2009, 26:666-675.

6. Walter J, Britton RA, Roos S: Host-microbial symbiosis in the vertebrate gastrointestinal tract and the Lactobacillus reuteri paradigm. Proc Natl Acad Sci U S A 2011, 108:4645-4652.

7. Gänzle MG, Vogel RF: Contribution of reutericyclin production to the stable persistence of Lactobacillus reuteri in an industrial sourdough fermentation. Int J Food Microbiol 2003, 80:31-45.

8. Meroth CB, Walter J, Hertel C, Brandt MJ, Hammes WP: Monitoring the bacterial population dynamics in sourdough fermentation processes by using PCR-denaturing gradient gel electrophoresis. Appl Environ Microbiol 2003, 69:475-482.

9. Vogelmann SA, Hertel C: Impact of ecological factors on the stability of microbial associations in sourdough fermentation. Food Microbiol 2011, 28:583-589.

10. Cotter PD, Hill C: Surviving the acid test: responses of Gram-positive bacteria to low pH. Microbiol Mol Biol Rev 2003, 67:429-453.

11. De Angelis M, Gobbetti M: Environmental stress responses in Lactobacillus: A review. Proteomics 2004, 4:106-122.

12. Kaditzki SJ, Behr J, Stocker A, Kaden P, Gänzle MG, Vogel RF: Influence of $\mathrm{pH}$ on the formation of glucan by Lactobacillus reuteri TMW 1.106 exerting a protective function against extreme $\mathrm{pH}$ values. Food Biotechnol 2008, 22:398-418.

13. Kim DS, Thomas S, Fogler HS: Effects of $\mathrm{pH}$ and trace minerals on longterm starvation of Leuconostoc mesenteroides. Appl Environ Microbiol 2000, 66:976-981.

14. Decock P, Cappelle S: Bread technology and sourdough technology. Trends in Food Science \& Technology 2005, 16:113-120.

15. Konings WN: The cell membrane and the struggle for life of lactic acid bacteria. Antonie Van Leeuwenhoek 2002, 82:3-27.

16. Rollan G, Lorca GL, Font de Valdez G: Arginine catabolism and acid tolerance response in Lactobacillus reuteri isolated from sourdough. Food Microbiol 2003, 20:313-319.
17. Thiele C, Gänzle MG, Vogel RF: Contribution of sourdough lactobacilli, yeast, and cereal enzymes to the generation of amino acids in dough relevant for bread flavor. Cereal Chemistry 2002, 79:45-51.

18. Vermeulen N, Gänzle MG, Vogel RF: Glutamine deamidation by cerealassociated lactic acid bacteria. J Appl Microbiol 2007, 103:1197-1205.

19. Lin J, Lee IS, Frey J, Slonczewski JL, Foster JW: Comparative analysis of extreme acid survival in Salmonella typhimurium, Shigella flexneri, and Escherichia coli. J Bacteriol 1995, 177:4097-4104.

20. Cotter PD, Gahan CG, Hill C: A glutamate decarboxylase system protects Listeria monocytogenes in gastric fluid. Mol Microbiol 2001, 40:465-475.

21. Sanders JW, Leenhouts K, Burghoorn J, Brands JR, Venema G, Kok J: A chloride-inducible acid resistance mechanism in Lactococcus lactis and its regulation. Mol Microbiol 1998, 27:299-310.

22. Higuchi $T$, Hayashi $H$, Abe $K$ : Exchange of glutamate and gammaaminobutyrate in a Lactobacillus strain. J Bacteriol 1997, 179:3362-3364.

23. Hiraga K, Ueno Y, Oda K: Glutamate decarboxylase from Lactobacillus brevis: activation by ammonium sulfate. Biosci Biotechnol Biochem 2008, 72:1299-1306.

24. Komatsuzaki N, Nakamura T, Kimura T, Shima J: Characterization of glutamate decarboxylase from a high gamma-aminobutyric acid (GABA)producer, Lactobacillus paracasei. Biosci Biotechnol Biochem 2008, 72:278-285.

25. Wesney E, Tannock GW: Association of rat, pig and fowl biotypes of lactobacilli with the stomach of gnotobiotic mice. Microb Ecol 1979, 5:35-42.

26. Stromeck A, Hu Y, Chen L, Gänzle MG: Proteolysis and bioconversion of cereal proteins to glutamate and gamma-aminobutyrate (GABA) in Rye malt sourdoughs. J Agric Food Chem 2011, 59:1392-1399.

27. Copeland ALS, Lapidus A, Barry K, Detter JC, Glavina del Rio T, Hammon N, Israni S, Dalin E, Tice H, Pitluck S, Sun H, Schmutz J, Larimer F, Land M, Hauser L, Walter J, Heng NCK, Tannock GW, Richardson P: Permanent Draft sequence of Lactobacillus reuteri 100-23. 2008,. US DOE Joint Genome Institute; 2008.

28. Kleerebezem M, Boekhorst J, van Kranenburg R, Molenaar D, Kuipers OP, Leer R, Tarchini R, Peters SA, Sandbrink HM, Fiers MW, et al: Complete genome sequence of Lactobacillus plantarum WCFS1. Proc Natl Acad SC U S A 2003, 100:1990-1995

29. Perez-Casal J, Price JA, Maguin E, Scott JR: An M protein with a single C repeat prevents phagocytosis of Streptococcus pyogenes: use of a temperature-sensitive shuttle vector to deliver homologous sequences to the chromosome of S. pyogenes. Mol Microbiol 1993, 8:809-819.

30. Su MS, Kao HC, Lin CN, Syu WJ: Gene 10017 encodes a second chaperone for EspA of enterohaemorrhagic Escherichia coli 0157: H7. Microbiology 2008, 154:1094-1103.

31. Sedgwick GW, Fenton TW, Thompson JR: Effect of protein precipitating agents on the recovery of plasma free amino acids. Canadian Journal of Animal Science 1991, 71:953-957.

32. Park KB, Oh SH: Cloning, sequencing and expression of a novel glutamate decarboxylase gene from a newly isolated lactic acid bacterium, Lactobacillus brevis OPK-3. Bioresour Technol 2007, 98:312-319.

33. Tannock GW, Ghazally S, Walter J, Loach D, Brooks H, Cook G, Surette M, Simmers C, Bremer P, Dal Bello F, Hertel C: Ecological behavior of Lactobacillus reuteri $100-23$ is affected by mutation of the luxS gene. Appl Environ Microbiol 2005, 71:8419-8425.

34. Minervini F, De Angelis M, Di Cagno R, Pinto D, Siragusa S, Rizzello CG, Gobbetti M: Robustness of Lactobacillus plantarum starters during daily propagation of wheat flour sourdough type I. Food Microbiol 2010, 27:897-908.

35. Scheirlinck I, Van der Meulen R, Van Schoor A, Vancanneyt M, De Vuyst L, Vandamme $P$, Huys $G$ : Taxonomic structure and stability of the bacterial community in belgian sourdough ecosystems as assessed by culture and population fingerprinting. Appl Environ Microbiol 2008, 74:2414-2423.

36. Siragusa S, Di Cagno R, Ercolini D, Minervini F, Gobbetti M, De Angelis ML: Taxonomic structure and monitoring of the dominant population of lactic acid bacteria during wheat flour sourdough type I propagation using Lactobacillus sanfranciscensis starters. Appl Environ Microbiol 2009, 75:1099-1109.

37. Foster JW: Escherichia coli acid resistance: tales of an amateur acidophile. Nat Rev Microbiol 2004, 2:898-907.

38. Rizzello CG, Cassone A, Di Cagno R, Gobbetti M: Synthesis of angiotenhsin I-converting enzyme (ACE)-inhibitory peptides and $\mathrm{y}^{-}$ 
aminobutyric acid (GABA) during sourdough fermentation by selected lactic acid bacteria. J Agric Food Chem 2008, 56:6936-6943.

39. Gänzle MG, Ehmann M, Hammes WP: Modelling of growth of Lactobacillus sanfranciscensis and Candida milleri in response to process parameters of the sourdough fermentation. Appl Environ Microbiol 1998, 64:2616-2623.

40. Brown G, Singer A, Proudfoot M, Skarina T, Kim Y, Chang G, Dementieva I, Kuznetsova E, Gonzalez C, Joachimiak A, Savchenko A, Yakunin AF: Functional and structural characterization of four glutaminases from Escherichia coli and Bacillus subtilis. Biochem 2008, 47:5724-5735.

41. Wieser $\mathrm{H}$, Koehler P: The biochemical basis of celiac disease. Cereal Chem 2008, 85:1-13

42. Poolman B, Smid EJ, Konings WN: Kinetic properties of a phosphatebond-driven glutamate-glutamine transport system in Streptococcus lactis and Streptococcus cremoris. J Bacteriol 1987, 169:2755-2761.

43. de Giori GS, Foucaud-Scheunemann C, Ferchichi M, Hemme D: Glutamate uptake in Lactobacillus delbrueckii subsp. bulgaricus CNRZ 208 and its enhancement by a combination of $\mathrm{Mn}^{2+}$ and $\mathrm{Mg}^{2+}$. Lett Appl Microbiol 2002, 35:428-432.

44. Walter J: Ecological role of lactobacilli in the gastrointestinal tract: implications for fundamental and biomedical research. Appl Environ Microbiol 2008, 74:4985-4996.

45. Walter J, Schwab C, Loach DM, Gänzle MG, Tannock GW: Glucosyltransferase A (GtfA) and inulosucrase (Inu) of Lactobacillus reuteri TMW1.106 contribute to cell aggregation, in vitro biofilm formation, and colonization of the mouse gastrointestinal tract. Microbiology 2008, 154:72-80.

46. Gänzle MG: Reutericyclin: biological activity, mode of action, and potential applications. Appl Microbiol Biotechnol 2004, 64:326-332.

doi:10.1186/1475-2859-10-S1-S8

Cite this article as: Su et al: Contribution of glutamate decarboxylase in Lactobacillus reuteri to acid resistance and persistence in sourdough fermentation. Microbial Cell Factories 2011 10(Suppl 1):S8.

\section{Submit your next manuscript to BioMed Central and take full advantage of:}

- Convenient online submission

- Thorough peer review

- No space constraints or color figure charges

- Immediate publication on acceptance

- Inclusion in PubMed, CAS, Scopus and Google Scholar

- Research which is freely available for redistribution

Submit your manuscript at www.biomedcentral.com/submit
Biomed Central 